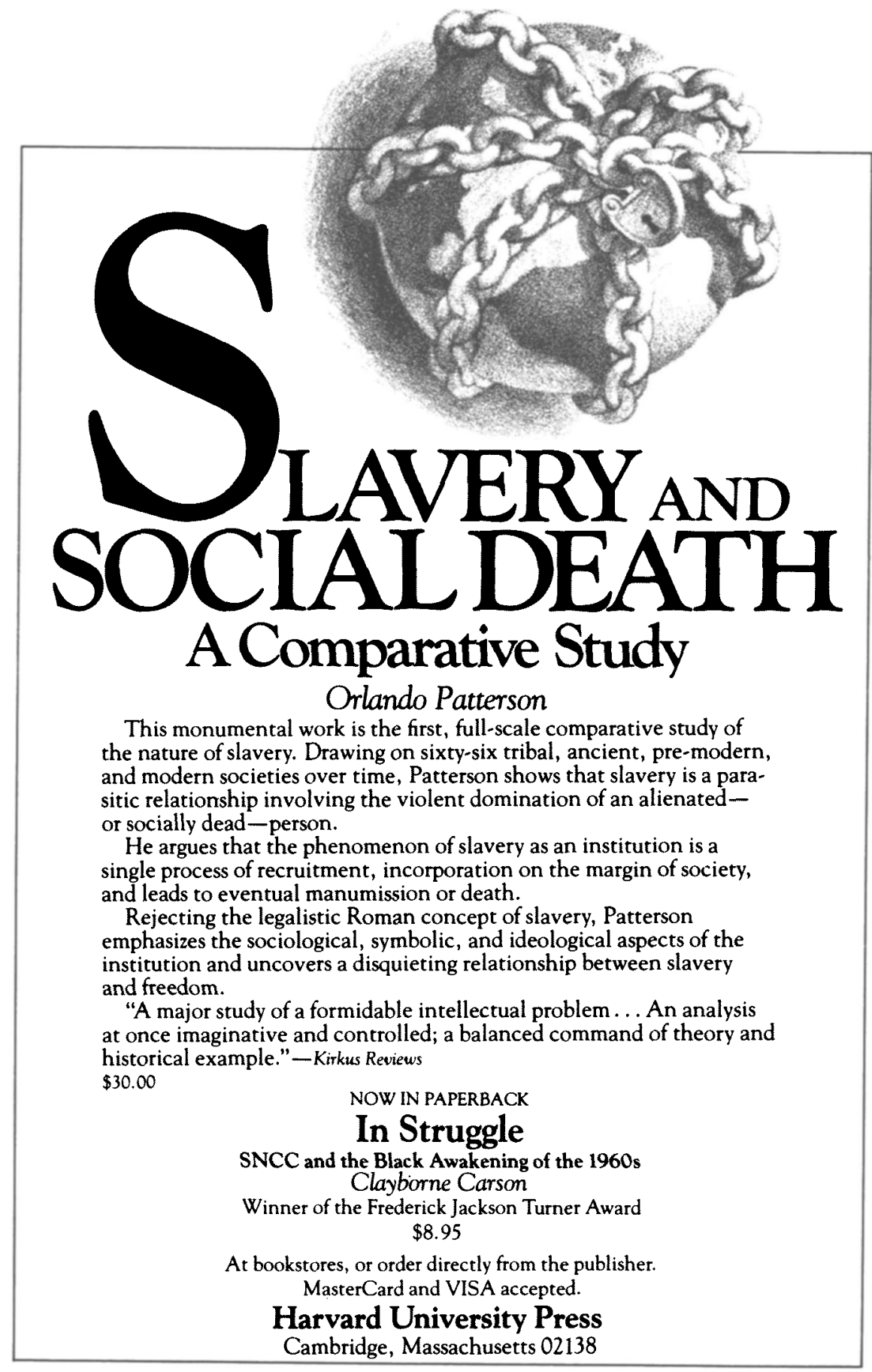




\section{Modern Germany}

Society, Economy and Politics in the Twentieth Century

V.R. Berghahn

Berghahn provides a comprehensive overview of the development of Germany in the 20th century, describing social change, economic performance and industrial relations, as well as politics and diplomacy. He pays much attention throughout to the lives and feelings of people. 47 tables, 4 maps

The Christian Polity of John Calvin

\section{H. Höpfl}

This examination of the relationship between Calvin's political thought and his practical political experience in Geneva and Strasbourg argues that his pre-Genevan writings show no evidence of a coherent political theory. Cambridge Studies in the History and Theory of Politics

$\$ 44.50$
Now in paperback...

English Culture and the Decline of the Industrial Spirit, 1850-1980 Martin J. Wiener

Winner of the 1981 Robert Livingston Schuyler Prize of the American Historical Association. "No rational reader could resist the impact of this book

"-The New Republic

Paper \$7.95

\section{Revolution in Miniature}

The History and Impact of Semiconductor

Electronics

Second Edition

Ernest Braun and

Stuart MacDonald

The second edition of a much acclaimed work has been largely rewritten and brought up to date

Paper \$9.95

\section{The Imperfect Peasant Economy}

The Loire County, 1800-1914

Gregor Dallas

Dallas shows how a rural household economy of smallholders managed to survive the century through adaptation.

\section{Paradoxical Harvest}

Energy and Explanation in British History, 1870-1914

\section{Richard Adams}

Studies the relationship between energy use and the general pattern of development in Great Britain. Hardcover $\$ 27.50$ Paper $\$ 8.95$

\section{Neostoicism and the Early Modern State Gerhard Oestreich}

B. Oestreich and H.G. Koenigsberger,

Editors

David McLintock, Translator

Cambridge Studies in Early Modern History $\$ 49.50$ 


\section{A Once Charitable Enterprise}

Hospitals and Healtb Care in New York and Brooklyn, 1885-1915

\section{David Rosner}

"Is a hospital a charitable social service with public functions, or a business enterprise sticking closely to the dictates of the market? Rosner describes in rich detail how this continuing dilemma was built into the culture; management, politics, and financing of the American hospital... Historians will welcome this wellwritten and timely book. . " - Rosemary Stevens, University of Pennsylvania \$29.50

\section{The Tudor Constitution}

Documents and Commentary

Second Edition

\section{G. R. Elton}

This major revision of a standard work takes into account the large amount of knowledge gained on the subject in the last twenty years.

Hardcover $\$ 59.50$ Paper $\$ 17.50$

\section{De Republica Anglorum}

\section{Sir Thomas Smith}

Mary Dewar, Editor

A new and more accurate edition of an important 16th century text that describes the social institutions, judicial systems, and governmental procedures of mid-Tudor England. Cambridge Studies in the History and Theory of Politics

\section{Exploring the} Urban Past

Essays in Urban History by H.J. Dyos

David Cannadine and

David Reeder, Editors

Brings together some of the most important work of one of the first urban historians.

Hardcover $\$ 39.50$ Paper $\$ 12.95$

\section{The Decline, Revival and Fall of the British Empire}

\section{J. A. Gallagher}

The major essays of Professor Gal. lagher are collected here, including the unpublished Ford Lectures on the British Empire and related papers on Africa, India, and imperialism. $\$ 29.50$

\section{Occupation Diplomacy}

Britain, the United States, and Japan, 1945-1952

\section{Roger Buckley}

Recently released official documents from British, American, and Japanese sources are used to challenge the view that the occupation was an exclusively American affair. International Studies

\section{Trinity College Dublin 1592-1952}

An Academic History

R. B. McDowell and D. A. Webb

\section{Cambridge University Press}




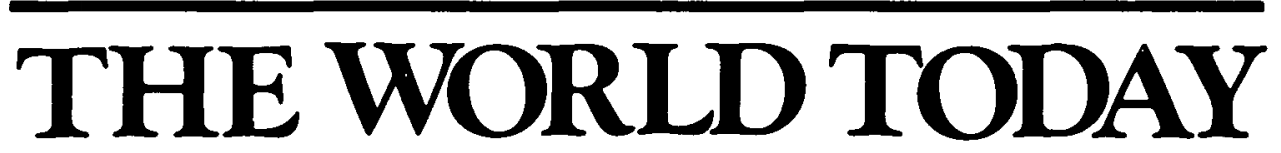

STUDENTS OF CURRENT AFFAIRS, to be well informed, need the facts. In THE WORLD TODAY, the monthly journal of the Royal Institute of International Affairs, experts bring to the general reader up-to-date and reliable information on world affairs.

Authoritative and objective, THE WORLD TODAY deals primarily with international problems but also includes articles on internal political and economic conditions in individual countries or regions, written by authors with first-hand knowledge. Short comment in 'Notes of the Month' puts current developments into perspective and provides a background to events of international significance.

Annual subscription (12 issues a year including postage inland and overseas) Vol. $38 \quad 1982$

\author{
USA $\$ 34$ \\ UK $\quad £ 12$ \\ Elsewhere $\quad £ 15$ \\ Published under the auspices of the \\ ROYAL INSTITUTE OF INTERNATIONAL AFFAIRS \\ LONDON \\ by the Oxford University Press \\ Walton Street, Oxford OX2 6DP
}


Comparative Studies in Society and History is a forum for presentation and discussion of new research into problems of change and stability that recur in human societies through time or in the contemporary world. It sets up a working alliance between specialists in all branches of the social sciences and humanities. Debate and review articles bring the general reader in touch with current findings and issues.

\section{NOTES FOR CONTRIBUTORS}

Contributions may be descriptive, analytical or theoretical. Any article not in itself comparative may be accepted if it lends itself to comment that will place it in comparative perspective. Correspondence with the editors prior to the submission of articles will help to enable them to obtain such comment or a companion study. Emphasis in comparative studies may be either on similarities or, if these are significant enough and call for some recasting of generalizations, on differences. All contributions and editorial correspondence should be sent to the Editors, Comparative Studies in Society and History, Department of History, University of Michigan, Ann Arbor, Michigan 48109.

Two copies of each contribution, preferably accompanied by a stamped, addressed envelope, should be submitted. Both text and footnotes should be clearly typed with double spacing and wide margins; footnotes should appear on separate pages at the end of the article. Illustrations may be included by arrangement with the editors.

Contributors will receive 50 offprints. Any additional offprints must be ordered on receipt of the first proof. 


\section{COMPARATIVE STUDIES IN SOCIETY AND HISTORY}

\section{Effects of Education}

LENORE O'Boyle Learning for Its Own Sake: The German University as Nineteenth-Century Model

C. R. DAY The Rustic Man: The Rural Schoolmaster in Nineteenth-Century France

Charles Camic Experience and Ideas: Education for Universalism in Eighteenth-Century Scotland

\section{Politics of Capitalist Agriculture}

ANTHONY Winson The Formation of Capitalist

Agriculture in Latin America and Its Relationship to

Political Power and the State

SUSAN ECKSTEIN Transformation of a "Revolution from

Below" - Bolivia and International Capital

\section{Metaphors of Revolution}

Bruce Lincoln "'The Earth Becomes Flat"-A Study of Apocalyptic Imagery

MARY Lowenthal Felstiner Family Metaphors: The Language of an Independence Revolution

Peter Burke From Pioneers to Settlers: Recent Studies of the History of Popular Culture. A Review Article

\section{Cambridge University Press}

The Pitt Building, Trumpington Street, Cambridge CB2 IRP

32 East 57 Street, New York, N.Y. 10022

296 Beaconsfield Parade, Middle Park, Melbourne 2306

(C) 1983 Society for the Comparative Study of Society and History 